\section{Bud Necrosis of Green Ash Nursery Trees Is Influenced by Nitrogen Availability and Fertilizer Type}

\author{
Carolyn F. Scagel ${ }^{1,4}$, Richard P. Regan ${ }^{2}$, and Guihong Bi ${ }^{3}$
}

ADDITIONAL INDEX WORDs. Fraxinus pennsylvanica, allocation, bud failure

Summary. A study was conducted to determine whether the nitrogen (N) status of nursery-grown green ash (Fraxinus pennsylvanica 'Summit') trees in the autumn is related to bud necrosis during the following spring. In 2005, different rates of $\mathrm{N}$ from urea formaldehyde (UF) or a controlled-release fertilizer (CRF) containing ammonium nitrate were applied during the growing season to green ash trees and leaves were sprayed or not with urea in the autumn. Biomass and $\mathrm{N}$ content was determined in Autumn 2005 and Spring 2006, and stem biomass and bud necrosis were evaluated for necrosis in Spring 2006. Trees with low N content in Autumn 2005 grew less in Spring 2006 but bud necrosis was more prevalent on trees grown at the highest $\mathbf{N}$ rate. Compared with trees grown with a similar amount of $\mathrm{N}$ from UF, growing trees with CRF altered $\mathrm{N}$ allocation in 2005 and the relationship between carbon (C) and $\mathrm{N}$ dynamics (import, export, and metabolism) in stems in 2006. Additionally, trees grown with CRF had less total shoot biomass in Spring 2006 and more bud failure than trees grown with a similar $\mathrm{N}$ rate from UF. Significant relationships between bud failure and $\mathrm{N}$ status and $\mathrm{C} / \mathrm{N}$ ratios in different tissues suggest that a combination of tree $\mathrm{N}$ status and the balance between $\mathrm{N}$ and $\mathrm{C}$ in certain tissues plays a role in the occurrence of bud failure of green ash trees in the spring.

$\mathrm{B}$ ud death (necrosis) and shoot dieback in the spring decrease the salability and growth of nursery trees. Bud necrosis and shoot dieback of green ash occurs periodically in nursery trees in the Pacific northwestern United States (PNW), affecting as much as half of the tree canopy. Pests and disease factors, including Verticillium dabliae and eriophyid mites (Acari spp.), can cause bud necrosis and shoot dieback in green ash; however, neither pests nor diseases have been correlated with similar symptoms in the spring (Pukacki and Przybył, 2005).

Poor shoot growth and dieback in the spring can be correlated with low nitrogen $(\mathrm{N})$ reserves in trees $(\mathrm{Bi}$ et al., 2005). Fertilizer management practices that increase tree $\mathrm{N}$ content, such as increasing rate of $\mathrm{N}$ application to soil (Bi et al., 2003; Cheng

${ }^{1}$ U.S. Department of Agriculture, Agricultural Research Service, Horticultural Crops Research Unit, 3420 NW Orchard Avenue, Corvallis, OR 97330

${ }^{2}$ Department of Horticulture, Oregon State University, North Willamette Research and Extension Center, Aurora, OR 97002-9543

${ }^{3}$ Department of Plant and Soil Sciences, Truck Crops Branch Experiment Station, Mississippi State University, 2024 Experiment Station Road, Crystal Springs, MS 39059

${ }^{4}$ Corresponding author. E-mail: Carolyn.Scagel@ars. usda.gov. et al., 2001) and foliar sprays in the autumn with urea, are used to increase $\mathrm{N}$ reserves and improve growth during the following growing season (Bi et al., 2005; Guak and Fuchigami, 2002). Two of the major factors controlling $\mathrm{N}$ availability from fertilizer are the total amount of $\mathrm{N}$ applied and the rate of release (Vallejo et al., 1993). Nitrogen availability, in turn, can influence nutrient uptake and resource partitioning (Scagel et al., 2008a, 2008b); therefore, to understand whether bud necrosis in green ash is related to tree $\mathrm{N}$ status, information on $\mathrm{N}$ uptake and partitioning is a necessary preliminary step. This type of information is also important for future hypotheses development that can give more in-depth insight into factors influencing bud necrosis.
The objectives of this study were to determine whether bud necrosis in green ash was associated with tree $\mathrm{N}$ status, and whether green ash trees containing the same amount of $\mathrm{N}$ from different types of fertilizer exhibited similar amounts of bud necrosis. Our initial working hypothesis was that trees containing low amounts of $\mathrm{N}$ in the autumn would exhibit a higher incidence of dieback the following spring than trees containing more $\mathrm{N}$, regardless of fertilizer type. The influence of tree $\mathrm{N}$ status on shoot dieback of green ash was evaluated by assessing bud necrosis on green ash grown with different rates of $\mathrm{N}$ from urea formaldehyde (UF) during the growing season and sprayed or not with urea in the autumn. Additionally, trees were also grown with one rate of an industry standard controlled-release fertilizer (CRF) that provided the same total $\mathrm{N}$ as the highest rate of UF.

\section{Materials and methods}

One-year-old bareroot field budded green ash (J. Frank Schmidt \& Sons, Boring, OR) were grown in 7 -gal containers using a douglas-firbased substrate at the Oregon State University North Willamette Research and Extension Center (NWREC) at Aurora, OR (lat. $45^{\circ} 22^{\prime} \mathrm{N}$, long. $\left.122^{\circ} 80^{\prime} \mathrm{W}\right)$. The container substrate was a commercial mix (Pro-Gro Mixes and Materials, Sherwood, OR) consisting of douglas-fir bark $(75 \%)$, pumice $(15 \%)$, and peatmoss (10\%) amended with micronutrients and dolomite limestone to obtain a $\mathrm{pH}$ of 6.7. A starter charge of 11.6 g N $(35 \% \mathrm{UF}+65 \%$ potassium nitrate) was incorporated to compensate for the $\mathrm{N}$ drawdown associated with bark substrates. The trees were grown on gravel under a retractable roof structure for the entire experiment and were irrigated with microsprinklers located at the surface of the

\begin{tabular}{llll}
\hline $\begin{array}{l}\text { Units } \\
\begin{array}{l}\text { To convert U.S. to SI, } \\
\text { multiply by }\end{array}\end{array}$ & U.S. unit & SI unit & $\begin{array}{l}\text { To convert SI to U.S., } \\
\text { multiply by }\end{array}$ \\
\hline 29.5735 & $\mathrm{fl} \mathrm{oz}$ & $\mathrm{mL}$ & 0.0338 \\
0.3048 & $\mathrm{ft}$ & $\mathrm{m}$ & 3.2808 \\
3.7854 & gal & $\mathrm{L}$ & 0.2642 \\
2.54 & inch $(\mathrm{es})$ & $\mathrm{cm}$ & 0.3937 \\
28.3495 & $\mathrm{oz}$ & $\mathrm{g}$ & 0.0353 \\
0.001 & $\mathrm{ppm}$ & $\mathrm{mg} \cdot \mathrm{g}^{-1}$ & 1000 \\
1 & $\mathrm{ppm}$ & $\mathrm{mg} \cdot \mathrm{L}^{-1}$ & 1 \\
$\left({ }^{\circ} \mathrm{F}-32\right) \div 1.8$ & ${ }^{\circ} \mathrm{F}$ & ${ }^{\circ} \mathrm{C}$ & $\left(1.8 \times{ }^{\circ} \mathrm{C}\right)+32$
\end{tabular}


container substrate of each tree. The roof of the structure remained open for the duration of the study and was only closed during brief periods of high winds. The trees were subject to outside air temperature and freeze events, with the lowest temperature of $-7{ }^{\circ} \mathrm{C}$ recorded on 17 Dec. 2005 and 20 Feb. 2006 by the AgriMet automated weather station located $100 \mathrm{~m}$ from the structure. Shoots in the tree canopy were not pruned.

The experiment was a randomized block design with five replications per $\mathrm{N}$ treatment (six) per urea treatment (two) per harvest (three). Nitrogen treatments consisted of trees receiving no $\mathrm{N}$ fertilizer $(0 \mathrm{~N})$, trees fertilized one of four rates of UF (4.2, 8.4, 16.8, or $33.6 \mathrm{~g}$ total $\mathrm{N}$ during the growing season from urea) on 10 Mar., 25 May, and 8 Aug. 2005 by incorporation into the top $5 \mathrm{~cm}$ of the growing substrate, or trees fertilized with a CRF $[18 \mathrm{~N}-2.6 \mathrm{P}-10.0 \mathrm{~K}$, $33.6 \mathrm{~g}$ total $\mathrm{N}$ from ammonium nitrate (Osmocote Classic (C); Scotts Horticulture, Marysville, $\mathrm{OH})]$ on 10 Mar. 2005 by incorporation at planting. Trees fertilized with UF also received $4.75 \mathrm{~g}$ of elemental phosphorus (from triple super phosphate) and $18.1 \mathrm{~g}$ of elemental potassium (from potassium sulfate) applied as split applications on 10 Mar. 2005 and 25 May 2005 to provide these required plant nutrients at a similar rate provided by the CRF treatment. The CRF rate and formulation for the CRF treatment was chosen based on results from previous experiments with this cultivar and was included in this study as a comparison with the highest $\mathrm{N}$ rate from UF. On 21 Sept. 2005 , leaves on trees in each fertilizer treatment were sprayed $(150 \mathrm{~mL}$ per tree) with a solution containing urea (+U; $30 \mathrm{~mL} \cdot \mathrm{L}^{-1}$ urea, $\left.46 \mathrm{~N}-0 \mathrm{P}-0 \mathrm{~K}\right)$ or with water ( $-\mathrm{U}$; urea treatment). Trees in all treatments were maintained in the greenhouse during the winter and were top-dressed with $180 \mathrm{~g}$ of CRF on 6 Feb. 2006, $\approx 35 \mathrm{~d}$ before budbreak for trees in the 33.6UF and 33.6-CRF treatments.

In Mar. 2005, before the start of $\mathrm{N}$ treatments, a total of 10 plants were harvested, separated by structure (2004 stems, 2005 stems, coarse roots, and fine roots), and the dry weight of each structure was determined. Oven-dried samples were ground and analyzed for $\mathrm{N}$ and $\mathrm{C}$ by automated combustion with an elemental analyzer using established methods (Scagel et al., 2007). The total content of $\mathrm{N}$ in trees was calculated from the sum of the $\mathrm{N}$ content in each structure based on weight and $\mathrm{N}$ concentration of each structure.

In Nov. 2005, after leaves had abscised, five trees in each $\mathrm{N}$ treatment by urea treatment combination were harvested, and the dry weight and $\mathrm{N}$ content of each structure were determined. Total $\mathrm{N}$ uptake between Mar. 2005 and Nov. 2005 was calculated by subtracting the average total tree $\mathrm{N}$ content in Mar. 2005 from the total tree $\mathrm{N}$ content of each tree in Nov. 2005. Nitrogen use efficiency [NUE (grams biomass per gram N uptake)] between Mar. 2005 and Nov. 2005 was estimated by dividing biomass by total $\mathrm{N}$ uptake. Net uptake of $\mathrm{N}$ from fertilizer between Mar. 2005 and Nov. 2005 was calculated by subtracting the $\mathrm{N}$ uptake of trees grown with no $\mathrm{N}$ fertilizer in 2005 (0N trees) from the total $\mathrm{N}$ uptake of each tree. Fertilize uptake efficiency [FUE (grams N uptake per gram N applied)] between Mar. 2005 and Nov. 2005 was estimated by dividing the net uptake of $\mathrm{N}$ from fertilizer by the total amount of $\mathrm{N}$ applied in 2005.

Bud performance data were recorded during Spring 2006 by determining the total number of buds per tree, and the number of viable buds as indicated by bud growth or bud failure by visual observation of tissue necrosis. In Apr. 2006 and May 2006, five trees in each $\mathrm{N}$ treatment by urea treatment combination were harvested, and the dry weight and $\mathrm{N}$ content of new stems (2006 stems and leaves) and old stems (2005 and 2004 stems) were determined.

All data were tested for homogeneity of variance using Levene's test and for normality using the ShapiroWilk W test. Biomass and composition data were analyzed separately for each harvest using a complete factorial two-way analysis of variance (ANOVA) with $\mathrm{N}$ treatment and urea treatment as main effects. Specific a priori contrasts were used to characterize the influence of $\mathrm{N}$ rate from UF on response variables and to compare means from trees fertilized with $33.6 \mathrm{~g}$ of $\mathrm{N}$ from CRF (33.6CRF) and trees fertilized with $33.6 \mathrm{~g}$ of $\mathrm{N}$ from UF (33.6-UF). Bud data did not meet assumptions of normality and homogeneity of variance, even after transformation; therefore, data were analyzed using the KruskalWallis ANOVA and Median Test, and means were separated at $P<$ $0.05\left(\mathrm{~K}-\mathrm{W}_{0.05}\right)$ to determine the influence of treatments on bud number and bud survival. Correlations between composition data and bud data were assessed using Spearman Rank R at $P<0.05$. All statistical analyses were performed with Statistica ${ }^{\circledR}$ Data Analysis Software System (version 8; StatSoft, Tulsa, OK).

Results from ANOVA and $\mathrm{K}-$ $\mathrm{W}_{0.05}$ indicated that spraying trees with urea in Autumn 2005 had no influence $(P>0.05$ for main effects or interaction between urea spray treatment and $\mathrm{N}$ treatment). Many studies have demonstrated the positive effects of urea sprays in the autumn on tree $\mathrm{N}$ status and new growth (Guak and Fuchigami, 2002); however, the effectiveness of urea sprays on tree $\mathrm{N}$ status can depend on the timing of application in relation to tree phenology and environmental conditions and the concentration of urea used in sprays (Bi et al., 2005). In our study, N status of green ash was not influenced $(P>0.05)$ by urea sprays; thus, the timing or concentration of the sprays was not optimal. All data presented are means pooled across urea treatments $(n=10)$. Errors used to make comparisons and contrasts were derived from full models that accounted for the variation associated with urea treatment.

\section{Results and discussion}

Nitrogen rate effects on 2005 CARBON AND NITROGEN DYNAMICS. Total biomass and $\mathrm{N}$ uptake between Mar. 2005 and Nov. 2005 increased, while $\mathrm{N}$ use efficiency decreased with increased rate of $\mathrm{N}$ application from UF in 2005 (Table 1). Biomass, $\mathrm{N}$ content, and $\mathrm{N}$ concentration in all tissues in Nov. 2005 increased, but $\mathrm{C} / \mathrm{N}$ ratios decreased with increasing rate of $\mathrm{N}$ application from UF in 2005 (Table 1). Increasing $\mathrm{N}$ rate decreased allocation of biomass and $\mathrm{N}$ to fine roots and 2004 stems in Nov. 2005 and increased biomass and $\mathrm{N}$ allocation to coarse roots and 2005 stems. The decrease in NUE with increasing $\mathrm{N}$ rate suggests $\mathrm{N}$ uptake in trees grown at the higher $\mathrm{N}$ rates was in excess of 
Table 1. Growth (biomass), nitrogen $(\mathrm{N})$ uptake, biomass allocation, $\mathbf{N}$ content, $\mathrm{N}$ allocation, and carbon-to-nitrogen $(\mathrm{C} / \mathrm{N})$ ratio of container-grown green ash in Nov. 2005 after growing for 9 months with different $\mathrm{N}$ rates and types of fertilizers [urea formaldehyde (UF) and controlled-release fertilizer (CRF)] in 2005.

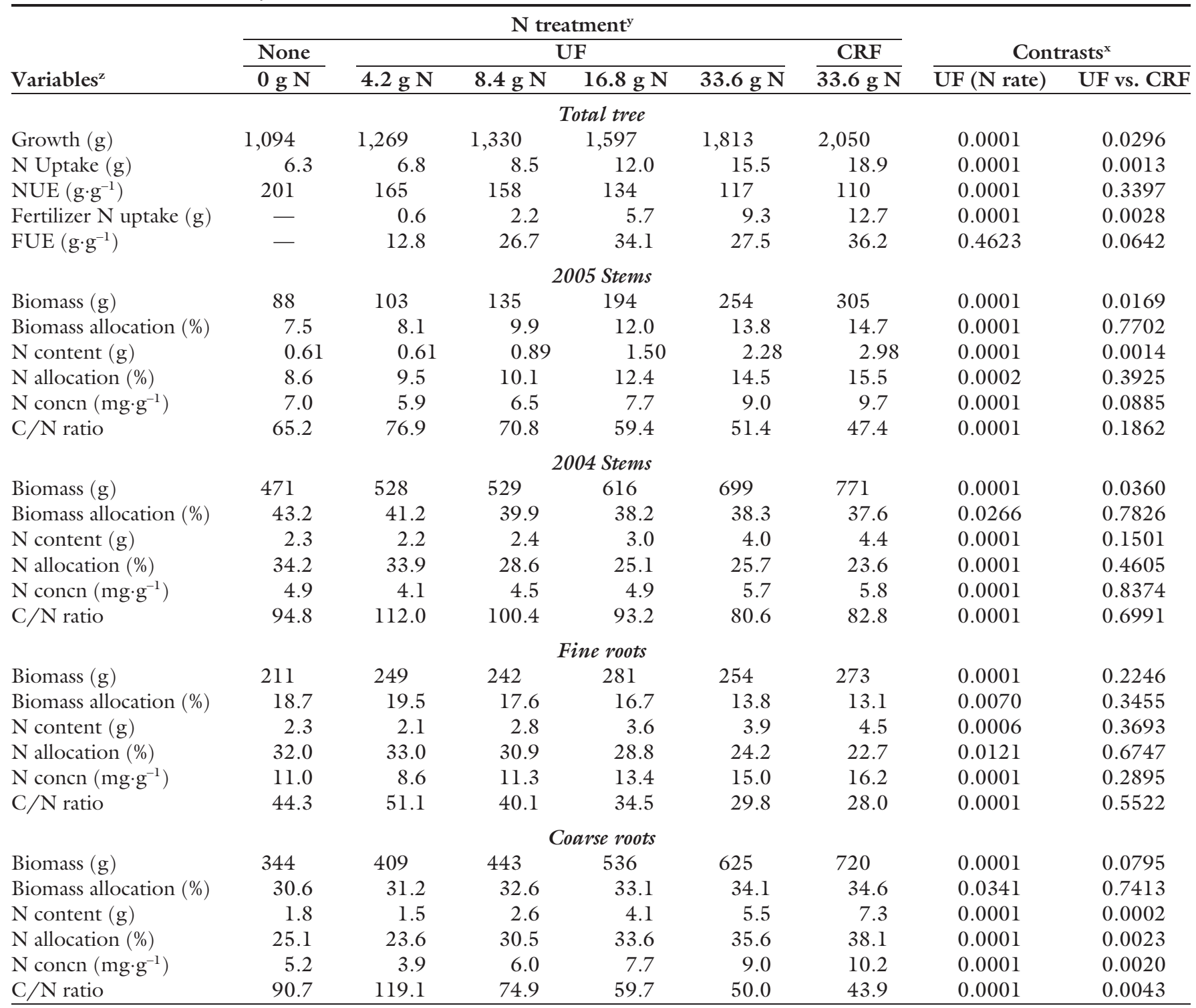

${ }^{\mathrm{z}}$ Growth $=$ net change in total biomass, $\mathrm{N}$ uptake $=$ net $\mathrm{N}$ accumulation, Fertilizer $\mathrm{N}$ uptake $=$ net $\mathrm{N}$ accumulation from fertilizer, $\mathrm{NUE}=\mathrm{N}$ use efficiency $($ grams biomass per gram N uptake), and FUE = fertilizer uptake efficiency (grams N uptake per gram N applied) for total tree between Mar. 2005 and Nov. 2005 . Biomass = dry weight, Biomass allocation $=$ proportion of total biomass, $\mathrm{N}$ content $=$ total $\mathrm{N}$ content, $\mathrm{N}$ allocation $=$ proportion of total tree $\mathrm{N}$ content $), \mathrm{N}$ concn $=\mathrm{N}$ concentration, and $\mathrm{C} / \mathrm{N}$ ratio for each tissue in Nov. 2005; $1 \mathrm{~g}=0.0353 \mathrm{oz} ; \mathrm{l} \mathrm{mg} \cdot \mathrm{g}^{-1}=1000 \mathrm{ppm}$.

${ }^{y}$ None $=$ trees received no N, UF = trees were fertilized from Mar. 2005 to Sept. 2005 with N from UF (total N applied: 4.2,8.4, 16.8, or 33.6 g N), CRF = trees fertilized with $\mathrm{N}$ at planting by incorporation of $33.6 \mathrm{~g}$ total $\mathrm{N}$ from a CRF $(18 \mathrm{~N}-2.6 \mathrm{P}-10.0 \mathrm{~K}$, Osmocote Classic (c); Scotts Horticulture, Marysville, OH).

${ }^{x}$ A priori contrasts results. UF (N rate): Pvalue for linear contrasts based on total N applied over growing season for trees fertilized with UF. There were no significant quadratic contrasts based on $\mathrm{N}$ rate. UF versus CRF: P value for differences between UF and CRF at $33.6 \mathrm{~g} \mathrm{~N}$.

the amount of $\mathrm{N}$ required solely for growth (e.g., storage) or growth may have been restricted for trees grown with higher $\mathrm{N}$ rates due to low availability of other nutrients. Optimal growth is obtained when there is a balanced ratio between nutrients (Huett, 1997a; Ingestad and Agren, 1991). High rates of $\mathrm{N}$ have been shown to induce deficiency of other nutrients (Scagel et al., 2008a, 2008b).

Fertilizer $\mathrm{N}$ uptake efficiency was lowest for trees grown with $4.2 \mathrm{~g}$ of $\mathrm{N}$ from UF, indicating that the influence of $\mathrm{N}$ availability on $\mathrm{N}$ uptake was a combined result of the amount of $\mathrm{N}$ in this treatment and a decreased ability to take up N. The FUE of trees grown with other $\mathrm{N}$ rates from $\mathrm{UF}$ were similar, indicating that the effects of $\mathrm{N}$ availability on $\mathrm{N}$ uptake was primarily a result of the amount of $\mathrm{N}$ in these treatments and not a direct effect on the trees ability to take up $\mathrm{N}$. Increasing the rate of $\mathrm{N}$ application can increase $\mathrm{N}$ availability to trees; however, it can also increase the $\mathrm{N}$ lost from container-grown plants and decrease the efficiency of fertilizer uptake (Huett, 1997b). Taken together, these results suggest that differences in tree performance during the following growing season between trees given different rates of $\mathrm{N}$ from UF may be a combined result of differences in tree $\mathrm{N}$ status, how $\mathrm{N}$ rate influences the trees ability to take up $\mathrm{N}$, and the influence of $\mathrm{N}$ availability on uptake of other nutrients. 
The availability of $\mathrm{N}$ during the growing season altered how trees allocated biomass and $\mathrm{N}$ (Table $\mathrm{l}$ ). Nitrogen availability can influence all components of plant growth, including $\mathrm{C}$ allocation and phenology (Dickson, 1989). Increasing $\mathrm{N}$ can commonly shift C allocation from roots to shoots. Our results indicate that $\mathrm{N}$ availability altered not only total biomass of green ash, but also how trees grow or allocate biomass and $\mathrm{N}$ resources; therefore, differences in tree performance (e.g., growth, bud necrosis) during the following growing season between trees given different rates of $\mathrm{N}$ may be a combined result of differences in tree $\mathrm{N}$ status and how $\mathrm{N}$ rate influences resource allocation and the relationship between $\mathrm{N}$ and $\mathrm{C}$ dynamics in different tissues.

Nitrogen rate effects on 2006 CARBON AND NITROGEN DyNAMICs. Between Nov. 2005 and Apr. 2006, N concentrations increased, $\mathrm{C}$ concentrations remained relatively stable, and $\mathrm{C} / \mathrm{N}$ ratios decreased in old stems of all fertilizer treatments (Table 2, C concentration data not shown). These results indicate that $\mathrm{N}$ translocation to old stems occurred between Nov. 2005 and Apr. 2006 without an appreciable change in $\mathrm{C}$ translocation. This increased $\mathrm{N}$ may be a combined result of translocation from other tissue in the early winter for storage and root uptake of $\mathrm{N}$ and mobilization of $\mathrm{N}$ from other tissues in spring for new growth.

The influence of $\mathrm{N}$ availability on $\mathrm{N}$ and $\mathrm{C}$ changes in green ash stems in the spring was greater on older stem tissues than new aboveground biomass. Between Apr. 2006 and May 2006, N concentrations in old stems of all UF trees remained stable, $\mathrm{C}$ concentrations and $\mathrm{C} / \mathrm{N}$ ratio in old stems of 16.8-UF and 33.6-UF trees decreased, and $\mathrm{C}$ concentrations and $\mathrm{C} / \mathrm{N}$ ratios in old stems of trees grown at lower $\mathrm{N}$ rates in 2005 remained stable (Table 2). In contrast, between Apr. 2006 and May 2006, biomass and $\mathrm{N}$ content (data not shown) of new stems of all UF trees increased, $\mathrm{N}$ concentrations and $\mathrm{C}$ concentrations decreased in new stems of 33.6-UF trees, and $\mathrm{C} / \mathrm{N}$ ratios remained relatively stable in new stems of all UF trees (Table 2). Between Apr. 2006 and May 2006, N mobilization and export in old stems of all UF trees was occurring at a similar rate as $\mathrm{N}$ import; however, 16.8-UF and 33.6-UF trees were actively exporting or metabolizing $\mathrm{C}$ at a rate disproportional to $\mathrm{N}$ accumulation, and trees with a lower $\mathrm{N}$ status were actively exporting or metabolizing $\mathrm{C}$ at a rate proportional to $\mathrm{N}$ accumulation during the same time. Between Apr. 2006 and May 2006, new aboveground biomass of UF trees was actively importing $\mathrm{N}$ at a rate consistent with $\mathrm{C}$ accumulation, and the decrease in $\mathrm{N}$ concentrations in new stems of 16.8-UF and 33.6-UF is a dilution effect of biomass on the amount of $\mathrm{N}$ in the stem.

Green ash trees fertilized with higher $\mathrm{N}$ rates from UF in 2005 were more active and had a higher demand for $\mathrm{C}$ from reserves in old stems earlier in the spring than trees fertilized with lower $\mathrm{N}$ rates. One applied implication of this observation is that pruning old stems may decrease the performance of high $\mathrm{N}$ status trees in the spring not just because of the loss of stored $\mathrm{N}$ but also because of the loss of carbon reserves. Pruning has been shown to decrease cold hardiness in abelia hybrids (Abelia) (Chappell and Robacker, 2006). There are conflicting reports concerning the influence of nutrient deficiency on tree cold tolerance and timing of spring growth. Some researchers have shown that nutrient-deficient trees acquire cold hardiness earlier in the

Table 2. Biomass, nitrogen $(\mathrm{N})$ concentration, and carbon to nitrogen $(\mathrm{C} / \mathrm{N})$ ratio of current year (2006) stems and old (2004 and 2005) stems from container-grown green ash in Nov. 2005, Apr. 2006, and May 2006 after growing for 9 months with different $\mathrm{N}$ rates and types of fertilizers [urea formaldehyde (UF) and controlled-release fertilizer (CRF)] in 2005.

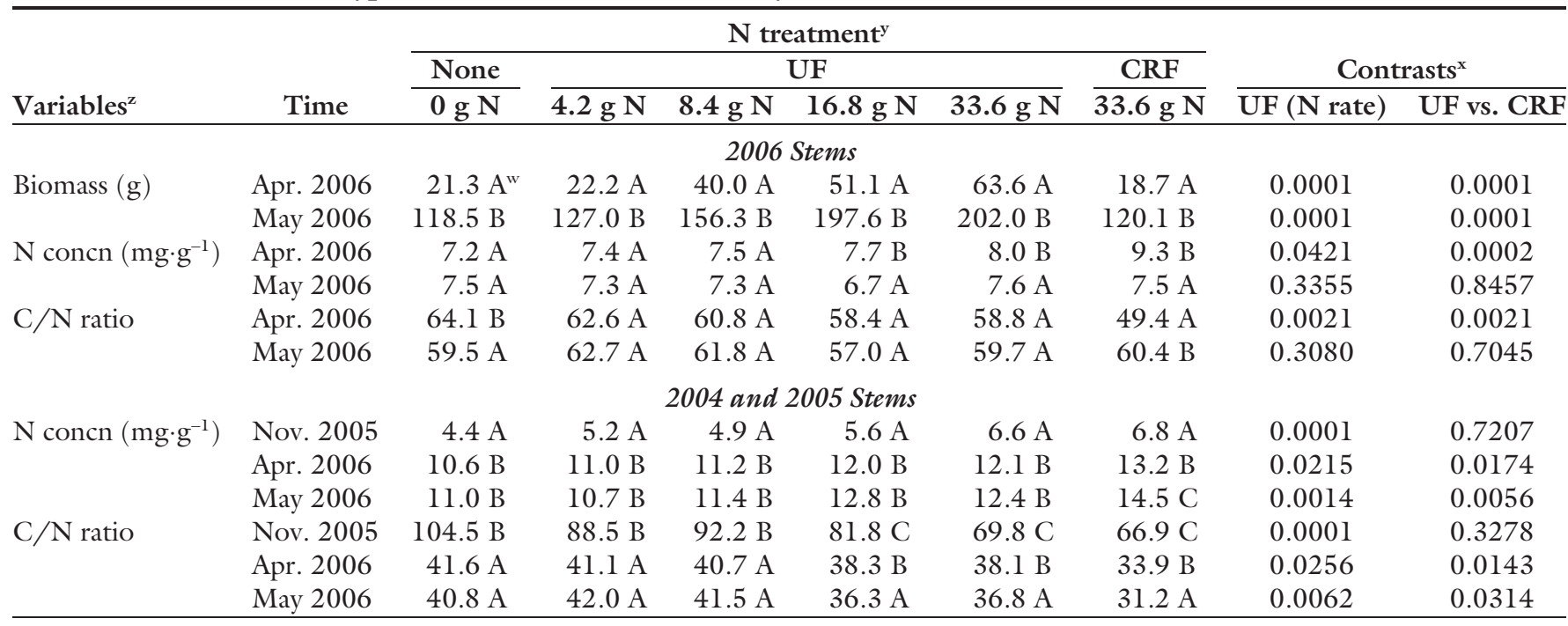

${ }^{2}$ Biomass = dry weight of new stems in Apr. 2006 and May 2006. N concn and C/N ratio for new and old stems in Nov. 2005 (old stems) and Apr. 2006 and May 2006 (new and old stems); $1 \mathrm{~g}=0.0353 \mathrm{oz} ; \mathrm{l} \mathrm{mg} \cdot \mathrm{g}^{-1}=1000 \mathrm{ppm}$

${ }^{y}$ None $=$ trees received no N, UF = trees were fertilized from Mar. 2005 to Sept. 2005 with N from UF (total N applied: 4.2, 8.4, 16.8 , or 33.6 g N), CRF = trees fertilized with $\mathrm{N}$ at planting by incorporation of $33.6 \mathrm{~g}$ total $\mathrm{N}$ from from a CRF (18N-2.6P-10.0K, Osmocote Classic $\odot$; Scotts Horticulture, Marysville, OH).

${ }^{x}$ A priori contrasts results. UF (N rate): $P$ value for linear contrasts based on total $\mathrm{N}$ applied over growing season for trees fertilized with UF. There were no significant quadratic contrasts based on $\mathrm{N}$ rate. UF versus CRF: $P$ value for differences between UF and CRF at $33.6 \mathrm{~g} \mathrm{~N}$.

"Means within a column and variable followed by the same upper case letter indicate no significant difference between dates for variable. 
autumn and become more cold hardy than trees grown at higher fertility rates and deficient trees become active later in the spring (Jalkanen et al., 1998). Others have shown that $\mathrm{N}$ deprivation reduces the level of hardiness (Colombo et al., 2003). Our results indicate that green ash trees with low $\mathrm{N}$ status become active later in the spring than trees grown with higher $\mathrm{N}$ rates from UF and if differences in bud necrosis during the following growing season are related to differences in tree $\mathrm{N}$ status, then it may be a result of low- $\mathrm{N}$-status trees being less prone to cold injury in the spring.

Nitrogen RATE EFFECTS ON TREE PERFORMANCE IN 2006. Increasing N rate from UF in 2005 increased the number of buds on stems, but had no influence $(P>0.05)$ on the number of failed buds or the percentage of failed buds in 2006 (Table 3). However, there were positive correlations between $\mathrm{N}$ concentrations in fine roots, coarse roots, and 2005 stems in Nov. 2005 and new stem biomass in Apr. $2006(\mathrm{R}>0.405 ; P<0.0062)$ and negative correlations between $\mathrm{C} /$ $\mathrm{N}$ ratios in coarse roots and fine roots in Nov. 2005 and new stem biomass in Apr. 2006 ( $\mathrm{R}<-0.438$; $P<$ 0.0052 ). Additionally, green ash trees with higher $\mathrm{N}$ concentrations in all tissues in Nov. 2005 and higher $\mathrm{N}$ concentrations in old stems in Apr. 2006 had more new stem biomass in May 2006 than trees with lower N concentrations ( $\mathrm{R}>0.470 ; P<$ 0.0007 ) and trees with lower $\mathrm{C} / \mathrm{N}$ ratios in all tissues in Nov. 2005 and lower $\mathrm{C} / \mathrm{N}$ ratios in old stems in Apr. 2006 had more new stem biomass in May 2006 than trees with higher C/ $\mathrm{N}$ ratios $(\mathrm{R}<-0.477 ; P<0.0001)$.

Table 3. Bud survival recorded in May 2006 from container-grown green ash after growing for 9 months with different $\mathrm{N}$ rates and types of fertilizers [urea formaldehyde (UF) and controlled-release fertilizer (CRF)] in 2005.

\begin{tabular}{|c|c|c|c|c|c|c|}
\hline \multirow[b]{3}{*}{ Variables } & \multicolumn{6}{|c|}{$\mathbf{N}$ treatment $^{\mathrm{z}}$} \\
\hline & \multirow{2}{*}{$\frac{\text { None }}{0 \mathrm{~g} \mathrm{~N}}$} & \multicolumn{4}{|c|}{ UF } & \multirow{2}{*}{$\frac{\text { CRF }}{33.6 \mathrm{~g} \mathrm{~N}}$} \\
\hline & & $4.2 \mathrm{~g} \mathrm{~N}$ & $8.4 \mathrm{~g} \mathrm{~N}$ & $16.8 \mathrm{~g} \mathrm{~N}$ & $33.6 \mathrm{~g} \mathrm{~N}$ & \\
\hline Total buds (no.) & $107 c^{y}$ & $138 \mathrm{bc}$ & $135 \mathrm{bc}$ & $165 \mathrm{~b}$ & $157 \mathrm{~b}$ & $219 a$ \\
\hline Viable buds (no.) & $67 \mathrm{ab}$ & $94 \mathrm{bc}$ & $99 \mathrm{c}$ & $114 \mathrm{c}$ & $99 \mathrm{c}$ & $46 \mathrm{a}$ \\
\hline Failed buds (no.) & $40 \mathrm{~b}$ & $44 \mathrm{~b}$ & $35 \mathrm{~b}$ & $51 \mathrm{~b}$ & $58 \mathrm{~b}$ & $173 a$ \\
\hline Failure (\%) & $37 \mathrm{~b}$ & $31 \mathrm{~b}$ & $26 \mathrm{~b}$ & $31 \mathrm{~b}$ & $35 \mathrm{~b}$ & $77 \mathrm{a}$ \\
\hline
\end{tabular}

${ }^{\mathrm{z}}$ None $=$ trees received no N, UF $=$ trees were fertilized from Mar. 2005 to Sept. 2005 with N from UF (total N applied: $4.2,8.4,16.8$, or $33.6 \mathrm{~g} \mathrm{~N}), \mathrm{CRF}=$ trees fertilized with $\mathrm{N}$ at planting by incorporation of $33.6 \mathrm{~g}$ total $\mathrm{N}$ from a CRF $(18 \mathrm{~N}-2.6 \mathrm{P}-10.0 \mathrm{~K}$, Osmocote Classic $($; Scotts Horticulture, Marysville, OH); $1 \mathrm{~g}=0.0353 \mathrm{oz}$.

Values within a row followed by the same lower case letter are not significantly different via Kruskal-Wallis Test at $P>0.05$.

These results suggest that new aboveground growth of green ash in April is dependent on tree $\mathrm{N}$ status from the following growing season as well as the balance between $\mathrm{C}$ and $\mathrm{N}$ storage in the roots. Later in the spring, new aboveground growth is dependant on the $\mathrm{N}$ status and stems. Taken suggest that the influence of $\mathrm{N}$ rate from UF on tree $\mathrm{N}$ status, resource allocation, and dynamics of $\mathrm{C}$ and $\mathrm{N}$ in different tissues are not a contributing factor to bud failure and only influence growth. New growth of pendence on $\mathrm{N}$ and $\mathrm{C}$ from storage and allocation of $\mathrm{C}$ and $\mathrm{N}$ toward, and mobilization from, storage pools has been described in many species (Bi et al., 2003; Chapin et al., 1990; Cheng et al., 2001; Tagliavini et al., 1998; Tromp, 1983); however, few esearchers have addressed the apimplications of the balance of 2005). Some researchers have shown that the $\mathrm{C} / \mathrm{N}$ ratio rather than carbohydrate or $\mathrm{N}$ status alone appears to play the predominant role in regulating various aspects of seedling growth, including storage reserve mobilizaand photosynthetic gene expression (Lattanzi et al., 2005; Martin et al., 2002).

Fertilizer tYPe eFFeCTS ON 2005 CARBON AND NITROGEN DYNAMICs. Total biomass and $\mathrm{N}$ uptake of 33.6-CRF trees were greater than 33.6-UF trees (Table 1). Fertilzer type (33.6-CRF vs. 33.6-UF on NUE, FUE, or biomass allocation of green ash trees (Table 1). The effects of fertilizer type on $\mathrm{N}$ and $\mathrm{C}$ varied between tissues and had the greatest influence on $\mathrm{N}$ and $\mathrm{C}$ of coarse roots (Table 1 ). Coarse roots from 33.6-CRF trees had similar biomass and greater $\mathrm{N}$ concentrations, $\mathrm{N}$ content, and $\mathrm{N}$ allocation and lower $\mathrm{C} / \mathrm{N}$ ratios than 33.6-UF trees. This lower $\mathrm{C} / \mathrm{N}$ ratio was a result of greater $\mathrm{N}$ allocation to coarse roots of 33.6-CRF trees and not less $\mathrm{C}$ in coarse roots.

The release of $\mathrm{N}$ by UF is primarily a function of decomposition by microorganisms as influenced by moisture and $\mathrm{pH}$, and $\mathrm{N}$ release by the CRF is primarily driven by temperature and moisture (Shaviv, 2001). The $\mathrm{N}$ released from UF is initially as urea, which can be readily taken up by trees or converted to other $\mathrm{N}$ forms in the substrate that are available for tree uptake and subject to leaching losses. The $\mathrm{N}$ released from CRF is initially as ammonium nitrate and although similarly subject to leaching losses, the potential for $\mathrm{N}$ loss from leaching is generally considered lower than with UF (Mikkelsen et al., 1994). These differences in $\mathrm{N}$ release mechanisms and $\mathrm{N}$ forms, as well as differences in availability of other macro- and micronutrients between the two fertilizer types used in this study, may have contributed to differences in the timing of $\mathrm{N}$ availability in the container substrate and resulted in differences in total $\mathrm{N}$ uptake and $\mathrm{N}$ allocation. Taken together, these results suggest that differences in tree performance during the following growing season between 33.6-CRF trees and 33.6-UF trees are not related to how trees take up $\mathrm{N}$ or their use of $\mathrm{N}$ for growth but may be related to the influence of fertilizer type on total $\mathrm{N}$ uptake, $\mathrm{N}$ allocation, and metabolic relationships between $\mathrm{C}$ and $\mathrm{N}$ in coarse roots.

Fertilizer type efFects ON 2006 CARBON AND NITROGEN DYNAMICS. The type of fertilizer applied to green ash trees during 2005 affected $\mathrm{N}$ and $\mathrm{C}$ in stems during Spring 2006 (Table 2). Between Apr. 2006 and May 2006, N concentrations in old stems of 33.6-CRF trees increased, $\mathrm{C}$ concentrations decreased, and $\mathrm{C} / \mathrm{N}$ ratio decreased. In contrast between Apr. 2006 and May 2006, N concentrations in old stems of 33.6-UF trees remained stable, 
and $\mathrm{C}$ concentrations and $\mathrm{C} / \mathrm{N}$ ratio decreased. These results indicate that between Apr. 2006 and May 2006, old stems of 33.6-CRF trees had a net accumulation of $\mathrm{N}$ (i.e., $\mathrm{N}$ import was more than $\mathrm{N}$ mobilization, metabolism, and export), while during the same time, there was no net accumulation of $\mathrm{N}$ in old stems of 33.6-UF trees (i.e., $\mathrm{N}$ mobilization, metabolism, and export occurred at a similar rate as $\mathrm{N}$ import). Between Apr. 2006 and May 2006, biomass, $\mathrm{N}$ content (data not shown), $\mathrm{C} / \mathrm{N}$ ratios of new stems of 33.6-CRF trees increased, $\mathrm{N}$ concentrations decreased, and $\mathrm{C}$ concentrations remained relatively stable. In contrast, between Apr. 2006 and May 2006, biomass and $\mathrm{N}$ content of new stems of 33.6-UF trees increased, $\mathrm{N}$ concentrations and $\mathrm{C}$ concentrations decreased, and $\mathrm{C} / \mathrm{N}$ ratios remained relatively stable. These results indicate that between Apr. 2006 and May 2006, new stems of 33.6CRF trees were actively importing $\mathrm{N}$ for new growth at a rate disproportional to $\mathrm{C}$ accumulation, and 33.6UF trees were actively importing $\mathrm{N}$ for new growth at a rate consistent with $\mathrm{C}$ accumulation.

The 33.6-CRF trees were more active and had a higher demand for $\mathrm{N}$ reserves from old stems earlier in the spring than 33.6-UF trees. Earlier metabolic activity in CRF trees suggests that CRF trees may become less cold hardy earlier in the spring than UF trees. There is little information available on the influence of fertilizer type on plant cold tolerance and timing of spring growth. Some researchers have demonstrated that treatment differences in foliar cation nutrition, and tree physiology, growth, and mortality better reflect absolute $\mathrm{N}$ treatment rates than they do the form of $\mathrm{N}$ applied (Birchler et al., 2001; Schaberg et al., 2002). Although some plant species have preferences for different forms of $\mathrm{N}$, the type of fertilizer used to deliver $\mathrm{N}$ may be more important for many plant species than the form of $\mathrm{N}$ (Schaberg et al., 2002). This may have to do with differences in timing of nutrient release, etc. Our results indicate that fertilizer type influences autumn $\mathrm{N}$ allocation and the timing of early spring $\mathrm{C}$ and $\mathrm{N}$ activity in stems of green ash. If differences in tree performance during the following growing season occur between
33.6-CRF trees and 33.6-UF trees, then predisposition to bud necrosis may be related to differences in autumn $\mathrm{N}$ allocation and timing of $\mathrm{C}$ and $\mathrm{N}$ import, export, and metabolism in the spring. Others have reported that low $\mathrm{C} / \mathrm{N}$ ratios in stems are associated with low cold tolerance, suggesting that the balance of $\mathrm{C}$ and $\mathrm{N}$ in stems is important for protection from winter injury (Thomas and Ahlers, 1999; Thomas and Blank, 1996).

Fertilizer type efFects ON TREE PERFORMANCE IN 2006. Trees grown with 33.6-CRF in 2005 had more buds and a higher percentage of failed buds in Spring 2006 than 33.6UF trees (Table 3). The 33.6-CRF trees had higher $\mathrm{N}$ concentrations in coarse roots and lower $\mathrm{C} / \mathrm{N}$ ratios in coarse roots in Nov. 2005 than 33.6UF trees (Table 1), and bud failure in Spring 2006 was negatively correlated with $\mathrm{N}$ concentrations in fine roots and coarse roots in Nov. 2005 $(\mathrm{R}<-0.453 ; P<0.0027)$ and positively related with $\mathrm{C} / \mathrm{N}$ ratios in fine roots and coarse roots in Nov. 2005 $(\mathrm{R}>0.466 ; P<0.0001)$. Additionally, 33.6-CRF trees had higher $\mathrm{N}$ concentrations and lower $\mathrm{C} / \mathrm{N}$ ratios in stems in Apr. 2006 than 33.6-UF trees (Table 2), and bud failure in Spring 2006 was positively related with $\mathrm{N}$ concentrations in old stems $(\mathrm{R}=0.474 ; P<0.0006)$ and negatively related with $\mathrm{C} / \mathrm{N}$ ratios in old stems $(\mathrm{R}=-0.489 ; P<0.0005)$. These significant relationships between bud failure, $\mathrm{N}$ status, and $\mathrm{C} / \mathrm{N}$ ratios in the autumn and the spring in different tissues suggest that a combination of tree $\mathrm{N}$ status and the balance between $\mathrm{N}$ and $\mathrm{C}$ in certain tissues may play a role in the occurrence of bud failure of green ash. Taken together, these results suggest that the influence of fertilizer type on $\operatorname{root} \mathrm{C}$ and $\mathrm{N}$ dynamics in the autumn and the timing of early spring changes in $\mathrm{C}$ and $\mathrm{N}$ in stems may be related to differences in bud failure between 33.6-CRF trees and 33.6-UF trees. We hypothesize that the influence of fertilizer type on bud failure is a result of differences in cold hardiness between trees grown with the different fertilizer types.

Winter injury to container- and field-grown trees and shrubs is often observed in nursery-grown plants in Oregon and other states in the PNW.
While severe freeze events do occur periodically in the PNW, winter injury can be observed under weather conditions that are considered only moderatly low temperature events. Although it is well known that application of $\mathrm{N}$ fertilizers late in the growing season can decrease cold hardiness and increase the potential for cold injury to buds and stems (Pellett et al., 1981; Thomas and Ahlers, 1999), the specific relationships between cold tolerance, plant $\mathrm{N}$ status, fertilizer formulations, and fertilizer application timing have not been well investigated for woody perennial nursery crops. It is possible that $\mathrm{N}$ fertilizer practices in the nursery contribute to cold tolerance of certain plant species. To our knowledge, the only information available on cold tolerance of green ash is from natural ecosystems and landscape plantings (Aniśko et al., 1994; Cappiello and Littlefield, 1994), and the applicability of this information to nursery production conditions is unknown.

\section{Conclusions and further questions}

Bud necrosis in green ash during the spring is associated with higher $\mathrm{N}$ concentrations and lower $\mathrm{C} / \mathrm{N}$ ratios in roots during the previous autumn and stems during the spring. Growing trees with CRF increased bud failure of green ash compared with trees fertilized with UF. Differences in bud failure between trees grown with CRF and UF were related to differences in $\mathrm{N}$ content, $\mathrm{N}$ partitioning, and $\mathrm{C} / \mathrm{N}$ ratios. Our results suggest that tree $\mathrm{N}$ status may play a role in bud necrosis and shoot dieback of green ash. However, the type of fertilizer used in production may have a larger effect on bud necrosis than $\mathrm{N}$ rate. This may have to do with differences in how trees metabolize different forms of $\mathrm{N}$, differences in nutrient release rates from fertilizers, where and when the $\mathrm{N}$ is stored, and how it is remobilized in the spring, especially in relation to $\mathrm{C}$ import, export, and metabolism.

\section{Literature cited}

Aniśko, T., O.M. Lindstrom, and G. Hoogenboom. 1994. Development of a cold hardiness model for deciduous woody plants. Physiol. Plant. 91:375-382. 
Bi, G., C.F. Scagel, L. Cheng, and L.H. Fuchigami. 2005. Effects of copper, zinc, and urea on defoliation and nitrogen reserves in nursery plants of almond. J. Hort. Sci. Biotechnol. 80:746-750.

Bi, G., C.F. Scagel, L. Cheng, S. Dong, and L.H. Fuchigmai. 2003. Spring growth of almond nursery trees depends upon both nitrogen reserves and spring nitrogen application. J. Hort. Sci. Biotechnol. 78:853-858.

Birchler, T.M., R.W. Rose, and D.L. Haase. 2001. Fertilization with $\mathrm{N}$ and K: Effects on Douglas-fir seedling quality and performance. West. J. Appl. For. 16: 71-79.

Cappiello, P.E. and L.E. Littlefield. 1994. Woody landscape plant cold-hardiness ratings. Maine Agr. For. Expt. Sta. Tech. Bul. 156.

Chapin, F.S., E.D. Schulze, and H.A. Mooney. 1990. The ecology and economics of storage in plants. Annu. Rev. Ecol. Syst. 21:423-447.

Chappell, M. and C. Robacker. 2006. The effect of mid-season pruning on the cold hardiness of six Abelia hybrids. Southern Nursery Assn. Res. Conf. Proc. 51:451453.

Cheng, L., S. Dong, S. Guak, and L.H. Fuchigami. 2001. Effects of nitrogen fertigation on reserve nitrogen and carbohydrate status and regrowth performance of pear nursery plants. Acta Hort. 564:5162.

Colombo, S.J., C.G. Lerum, and D.P. Webb. 2003. Daylength, temperature, and fertilization effects on desiccation resistance, cold hardiness, and root growth potential of Picea mariana seedlings. Ann. For. Sci. 60:307-317.

Dickson, R.E. 1989. Carbon and nitrogen allocation in trees. Ann. Sci. For. 46:631s-647s.

Guak, S. and L.H. Fuchigami. 2002. Foliar applications of urea or ABA affect growth cessation, leaf senescence and abscission, cold acclimation and levels of reserve nitrogen and carbohydrates in nitrogen-treated apple nursery plants. J. Hort. Sci. Biotechnol. 77:137-142.

Huett, D.O. 1997a. Fertiliser use efficiency by containerized nursery plants. 1 . Plant growth and nutrient uptake. Aust. J. Agr. Res. 48:251-258.

Huett, D.O. 1997b. Fertiliser use efficiency by containerized nursery plants. 2 . Nutrient leaching. Aust. J. Agr. Res. 48: 259-265.

Ingestad, T. and G.I. Agren. 1991. The influence of plant nutrition on biomass allocation. Ecol. Appl. 1:168-174.

Jalkanen, R.E., D.B. Redfern, and L.J. Sheppard. 1998. Nutrient deficits increase frost hardiness in sitka spruce (Picea sitchensis) needles. For. Ecol. Mgt. 107:191201.

Lattanzi, F.A., H. Schnyder, and B. Thornton. 2005. The sources of carbon and nitrogen supplying leaf growth. Assessment of the role of stores with compartmental models. Plant Physiol. 137: 383-395.

Martin, T., O. Oswald, and I.A. Graham. 2002. Arabidopsis seedling growth, storage lipid mobilization, and photosynthetic gene expression are regulated by carbon:nitrogen availability. Plant Physiol. 128:472-481.

Mikkelsen, R.L., H.M. Williams, and A.D. Behel, Jr. 1994. Nitrogen leaching and plant uptake from controlled-release fertilizers. Fert. Res. 37:43-50.

Pellett, H., M. Gearhart, and M. Dirr. 1981. Cold hardiness capability of woody ornamental plant taxa. J. Amer. Soc. Hort. Sci. 106:239-243.

Pukacki, P.M. and K. Przybył. 2005. Frost injury as a possible inciting factor in bud and shoot necroses of Fraxinus excelsior L. J. Phytopathol. 153:512-516.

Scagel, C.F., G. Bi, L.H. Fuchigami, and R.P. Regan. 2008a. Rate of nitrogen application during the growing season and spraying plants with urea in the autumn alters uptake of other nutrients by deciduous and evergreen container- grown Rhododendron cultivars. HortScience 43:1569-1579.

Scagel, C.F., G. Bi, R.P. Regan, and L.H. Fuchigami. 2007. Seasonal variation in growth, nitrogen uptake and allocation by container-grown Rbododendron cultivars. HortScience 45:1440-1449.

Scagel, C.F., G. Bi, R.P. Regan, and L.H. Fuchigami. 2008b. Nitrogen availability alters mineral nutrient uptake and demand in container-grown deciduous and evergreen Rhododendron. J. Environ. Hort. 26:177-187.

Schaberg, P.G., D.H. DeHayes, G.J. Hawley, P.F. Murakami, G.R. Strimbeck, and S.G. McNulty. 2002. Effects of chronic $\mathrm{N}$ fertilization on foliar membranes, cold tolerance, and carbon storage in montane red spruce. Can. J. For. Res. 32:1351-1359.

Shaviv, A. 2001. Advances in controlledrelease fertilizers. Adv. Agron. 71:2-45.

Tagliavini, M., P. Millard, and M. Quartieri. 1998. Storage of foliar-absorbed nitrogen and remobilization for spring growth in young nectarine (Prunus persica var. nectarina) trees. Tree Physiol. 18:203-207.

Thomas, F.M. and R. Blank. 1996. The effect of excess nitrogen and of insect defoliation on the frost hardiness of bark tissue of adult oaks. Ann. Sci. For. 53: 395-406.

Thomas, F.M. and U. Ahlers. 1999. Effects of excess nitrogen on frost hardiness and freezing injury of above-ground tissue in young oaks (Quercus petraea and $Q$. robur). New Phytol. 144:73-83.

Tromp, J. 1983. Nutrient reserves in roots of fruit trees, in particular carbohydrates and nitrogen. Plant Soil 71:401413.

Vallejo, A., M.C. Cartagena, D. Rodriguez, and J.A. Diez. 1993. Nitrogen availability of soluble and slow release nitrogen fertilizers as assessed by electroultrafiltration. Nut. Cycling Agroecosytems 34:1385-1414. 